Penelitian

\title{
Gambaran Histologi dan Histomorfometri Penis Kuda Gayo
}

\author{
(Histology and Histomorphometry Description of Gayo Horse Penis)
}

\author{
Juli Melia', Morteza Almuthahhar'2, Muslim Akmal', Al Azhar' \\ ${ }^{1}$ Laboratorium Reproduksi Fakultas Kedokteran Hewan Universitas Syiah Kuala \\ ${ }^{2}$ Program Studi Pendidikan Dokter Hewan Fakultas Kedokteran Hewan Universitas Syiah Kuala \\ ${ }^{3}$ Laboratorium Histologi Fakultas Kedokteran Hewan Universitas Syiah Kuala \\ ${ }^{4}$ Laboratorium Biokimia Fakultas Kedokteran Hewan Universitas Syiah Kuala \\ *Penulis untuk korespondensi: julimelia@unsyiah.ac.id \\ Diterima 16 April 2021, Disetujui 8 Oktober 2021
}

\begin{abstract}
ABSTRAK
Penis kuda adalah alat kopulasi utama pada kuda. Penelitian ini bertujuan untuk mengetahui gambaran histologi dan histomorfometri penis pada kuda gayo. Sampel penelitian menggunakan penis dari 3 ekor kuda gayo jantan berumur 510 tahun yang dipotong di Rumah Potong Hewan Dolok Sanggul, Humbang Hasundutan, Sumatera Utara. Proses mikroteknik dilakukan terhadap sampel menggunakan pewarnaan hematoksilin-eosin (HE). Pengamatan struktur histologi menggunakan mikroskop dan dilakukan pengukuran ketebalan lapisan epitel uretra, ketebalan tunika albugenia di corpora cavernosa dan corpus spongiosum radix, corpus, dan glans penis menggunakan program aplikasi toupview. Hasilnya dibahas secara deskriptif. Hasil penelitian menunjukkan gambaran histologi penis kuda gayo terdiri atas dua jaringan erektil yaitu corpora cavernosa dan corpus spongiosum serta satu uretra. Sinusoid cavernosal dari corpus cavernosum mengandung banyak trabekula yang terdiri atas jaringan ikat fibroelastis, serat otot polos dan fibroblas. Corpus spongiosum memiliki trabekula yang lebih tipis dengan ruang kavernosa yang lebih besar. Corpus cavernosum dan corpus spongiosum ditutup oleh tunika albuginea. Uretra terdiri atas berbagai epitel, seperti epitel berlapis transisional, epitel kolumnar berlapis dan epitel skuamosa. Pengukuran histomorfometri menunjukkan bahwa ketebalan tunika albugenia radix dan corpus penis kuda gayo berturut-turut adalah 2.181,10 $\pm 48,50 \mu \mathrm{m}$, dan 2.366,51 \pm $131,48 \mu \mathrm{m}$., sedangkan ketebalan lapisan epitel uretra adalah 50,02 $\pm 6,95 \mu \mathrm{m}$. Kesimpulannya adalah penis kuda gayo terdiri atas radix, corpus dan glans penis. Radix dan corpus penis kuda gayo terdiri atas jaringan ikat, otot polos dan sinusoid cavernosal; glans penis terdapat sinus uretra.
\end{abstract}

Kata kunci : histologi, kuda gayo jantan, radix, corpus, glans penis

\begin{abstract}
The penis is the main copulation system of stallions. This study aims to determine the histological and histomorphometry features of the Gayo stallion penis. Samples used were the penis obtained from 3 stallions aged 5-10 years old, slaughtered at the Dolok Sanggul slaughterhouse, Humbang Hasundutan, North Sumatra. Microtechnical processes were performed on samples using hematoxylin-eosin (HE) staining. Microscope was used to observe the histological structure and measure the thickness of the urethra epithelial layer, thickness of the tunica albuginea in the corpora cavernosa and the corpus spongiosum of radix, corpus, and glans penis by using a toupview application program. The results were discussed descriptively. The results show that the penis of the Gayo horses consist of two erectile tissues called corpora cavernosa and corpus spongiosum; and one urethra. Cavernosal sinusoid of corpus cavernosum contains a lot of trabeculae consisting of fibroelastic connective tissue, smooth muscle fibers, and fibroblasts. Due to its thin trabecula, corpus spongiosum has larger cavernous space than corpus cavernosum. Corpora cavernosa and corpus spongiosum are covered by tunica albuginea. The urethra consists of various epithelium, such as transitional layered epithelium, layered columnar epithelium, and squamous epithelium. The histomorphometry measurement shows that the thickness of tunica albuginea of the radix and corpus of Gayo horse penis are 2,181.10 \pm $48.50 \mu \mathrm{m}$ and 2,366.51 $\pm 131.48 \mu \mathrm{m}$, respectively, whereas the thickness of epithelium urethra layer is $50.02 \pm 6.95 \mu \mathrm{m}$. The conclusion shows that the Gayo horse penis consists of radix, corpus, and glans penis. The radix and corpus penis consists of connective tissue, smooth muscle, and cavernosal sinusoids. The glans penis contains the urethral sinus.
\end{abstract}

Keywords: histology, Gayo stallion, radix, corpus, glans penis 


\section{PENDAHULUAN}

Indonesia memiliki 11 jenis kuda lokal yang tersebar di wilayah tertentu. Penamaan kuda lokal umumnya berdasarkan asal daerah seperti kuda gayo, kuda batak, kuda jawa, kuda priangan, kuda sulawesi, kuda lombok, kuda bali, kuda sumbawa, kuda sandel, kuda timor, dan kuda flores (Suarjono yang disitasi oleh Melia 2017). Berdasarkan Surat Keputusan Menteri Pertanian Republik Indonesia No. 1054/Kpts/SR.120/10/2014 dinyatakan bahwa kuda gayo merupakan salah satu rumpun kuda asli di Indonesia. Secara umum, kuda gayo memiliki karakteristik yang hampir sama dengan kuda lokal lain di Indonesia, namun kuda gayo memiliki beberapa keunikan antara lain bentuk kepala yang lurus seperti kuda thorougbred tetapi ukurannya lebih kecil, surainya yang lebat dan kaku serta telinganya yang menyerupai telinga keledai menjadi ciri khas dari kuda gayo (Melia 2017).

Umumnya, kuda-kuda lokal di Indonesia digunakan sebagai sarana transportasi dan pengangkut barang, sarana hiburan, dan juga sebagai bahan pangan masyarakat lokal (Harisatria et al. 2017). Arifiantini et al. (2007) menyebutkan bahwa, populasi kuda, terutama kuda di Indonesia terus menurun, penurunan tersebut diduga terkait dengan tingginya angka pemotongan yang didorong oleh kesulitan ekonomi peternak, pengafkiran oleh berbagai sebab, dan rendahnya angka kelahiran. Berdasarkan data dari Direktokrat Jendral Peternakan dan Badan Pusat Statistik diperoleh informasi populasi kuda mencapai 582.300 ekor pada tahun 1997, dan 452.900 pada tahun 2003. Sementara, data dari Dinas Peternakan dan Perikanan Aceh Tengah diperoleh informasi bahwa terjadi penurunan populasi kuda gayo yang cukup drastis dari tahun 2010-2014 yaitu dari 2.812 menjadi 755 ekor. Analisis eksponensial menunjukkan kuda gayo akan terancam punah pada tahun 2037 jika tidak dilakukan upaya penyelamatan (Melia et al. 2016). Oleh karena itu, perlu dilakukan suatu upaya untuk peningkatan populasi kuda gayo diantaranya dari segi aspek reproduksi.

Reproduksi merupakan kemampuan makhluk hidup untuk menghasilkan keturunan yang baru. Tujuannya adalah untuk mempertahankan dan melestarikan jenisnya agar tidak punah supaya keseimbangan alam tetap terjaga. Upaya pelestarian kuda gayo salah satunya dapat dilakukan dengan peningkatan keberhasilan program breeding. Untuk mendukung upaya tersebut diperlukan pengetahuan tentang reproduksi pada kuda kuda gayo. Sampai saat ini, sangat sulit diperoleh data tentang reproduksi kuda gayo, bahkan belum dijumpai adanya literatur tentang reproduksi pada kuda gayo jantan.

Organa genetalia kuda jantan terdiri dari penis, kelenjar asesoris (kelenjar prostat, kelenjar bulbouretralis, kelenjar vasikula), ampula, vas deferens, epididimis, dan testis (Brinsko 1998; Kareskoski dan Katila 2008; Morel 2008). Penis terletak dalam selubung kulit abdomen dan berujung pada preputium sebagai gerbang pintu penghubung dengan dunia luar (Ulum et al. 2013). Penis kuda dapat dibagi dalam 3 bagian, yaitu radix, corpus, dan glans penis (Morel 2008). Penis kuda diklasifikasikan sebagai tipe penis vascular, karena pentingnya ruang-ruang kosong di corpus cavernosum, serta banyak ruang darah dan tunika albuginea. Pada hewan ruminansia dan babi hutan memiliki ruang cavernous yang kurang luas dan lebih banyak jaringan ikatnya, serta ruang darah yang kecil dan tunika albuginea yang tebal (Dawood 2018).

Terdapat beberapa kelainan pada penis antara lain, paraphimosis merupakan kondisi ketidakmampuan penis untuk menarik kembali ke dalam, biasanya hal ini terjadi secara kongenital atau didapatkan setelah perawatan dengan obat penenang; equine herpesvirus (EHV)-3 yang menyebabkan pustular dan ulceratif balanoposthitis; pyogranulomatous balanitis; habronemiasis; dan karsinoma sel squamosa (Schmacher dan Hardin 1987 dan Momen et al. 1988).

Sampai saat ini, sangat sulit diperoleh data tentang reproduksi kuda gayo bahkan penelitian yang membahas histologi organ reproduksi kuda lokal di Indonesia khususnya kuda gayo jantan belum ditemukan, padahal ini sangat bermanfaat sebagai ilmu dasar reproduksi dan histologi terkait pengaplikasian teknologi reproduksi dan teknik diagnosa gangguan reproduksi pada kuda jantan. Berdasarkan latar belakang tersebut, maka perlu dilakukan penelitian tentang gambaran normal histologi organ reproduksi kuda gayo jantan, termasuk histologi dan histomorfometri penis.

Penelitian ini bertujuan untuk mengetahui gambaran histologi dan histomorfometri penis kuda gayo dengan harapan dapat memberikan informasi data awal mengenai gambaran histologi dan histomorfometri penis kuda gayo serta menjadi dasar untuk diagnosa gangguan reproduksi secara histopatologis, dan sebagai referensi untuk penelitianpenelitian selanjutnya. 


\section{BAHAN DAN METODE}

Alat dan Bahan

Alat-alat yang digunakan pada penelitian ini adalah wadah penyimpan organ, gelas ukur, surgery minor set, cawan petri, kertas tissue, staining jar, mikrotom, pisau mikrotom, kertas label, gelas objek, gelas penutup, mesin vacuum, pipet tetes, pipet volume, inkubator $60^{\circ} \mathrm{C}$, embedding processor, slide warmer $37^{\circ} \mathrm{C}$, waterbath, mikroskop cahaya (Olympus $\left(\mathrm{C}_{31}\right)^{\oplus}$, kamera mikroskop Sigma ${ }^{\oplus}$ dan toupview application program.

Bahan-bahan yang digunakan dalam penelitian ini adalah penis kuda gayo, larutan $\mathrm{NaCl}$ fisiologis 0,9\%, Phosphate Buffered Saline (PBS) 10\% sebagai larutan fiksatif, silol, akuades, alkohol dengan konsentrasi bertingkat (70\%, 80\%, 90\%, 95\% dan absolut), hematoksilin-eosin (HE), parafin, dan bahan perekat Entellan ${ }^{\circledR}$.

\section{Metode Penelitian}

Penelitian ini adalah penelitian eksploratif, menggunakan penis dari 3 ekor kuda gayo jantan berumur 5-10 tahun, dan sehat secara reproduksi. Sampel kemudian dibuat menjadi preparat histologi dan diwarnai dengan pewarnaan $\mathrm{HE}$ serta dilakukan pengukuran pada ketebalan lapisan epitel uretra, ketebalan tunika albugenia pada corpora cavernosa dan corpus spongiosum pada bagian radiks, korpus, dan glans penis dengan menggunakan toupview application program. Data yang diperoleh disajikan dalam bentuk gambar histologi dan ditabulasikan dalam bentuk rataan \pm simpangan baku dan kemudian dianalisis secara deskriptif.

\section{Prosedur Penelitian}

\section{Pengambilan Sampel Penis}

Pengambilan penis dilakukan setelah kuda dipotong di Rumah Potong Hewan Dolok Sanggul, Kabupaten Humbang Hasundutan, Sumatera Utara. Penis diambil dan dibersihkan dari sisa-sisa jaringan yang melekat. Setelah itu, sampel dibilas menggunakan $\mathrm{NaCl}$ fisiologis $0.9 \%$ sampai bersih dan dimasukkan ke dalam larutan fiksatif PBS 10\%. Selanjutnya dilakukan sedikit pengambilan sampel dengan cara incisi $( \pm 2 \mathrm{~cm}$ ) pada daerah radix, corpus dan glans penis untuk pembuatan preparat histologis. Setiap sampel diberikan label lalu dipindahkan ke dalam larutan alkohol $70 \%$ sebagai stopping point sampai dilakukan proses dehidrasi.

\section{Pembuatan Preparat Histologi}

Pengambilan penis dilakukan setelah kuda dipotong di Rumah Potong Hewan Dolok Sanggul, Kabupaten Humbang Hasundutan, Sumatera Utara. Penis diambil dan dibersihkan dari sisa-sisa jaringan yang melekat. Setelah itu, sampel dibilas menggunakan $\mathrm{NaCl}$ fisiologis $0.9 \%$ sampai bersih dan dimasukkan ke dalam larutan fiksatif PBS 10\%. Selanjutnya dilakukan sedikit pengambilan sampel dengan cara incisi $( \pm 2 \mathrm{~cm})$ pada daerah radix, corpus dan glans penis untuk pembuatan preparat histologis. Setiap sampel diberikan label lalu dipindahkan ke dalam larutan alkohol $70 \%$ sebagai stopping point sampai dilakukan proses dehidrasi.

\section{Pembuatan Preparat Histologi}

Pembuatan preparat histologi penis mengacu pada metode Kiernan (1990). Proses tersebut dimulai dengan dehidrasi jaringan menggunakan larutan alkohol konsentrasi bertingkat (80\%, 90\%, 95\%, absolut I dan absolut II), penjernihan dengan larutan silol, infiltrasi jaringan dalam parafin, infiltrasi sebanyak tiga kali pengulangan, dan dilanjutkan dengan penanaman (embedding) dalam parafin cair hingga menjadi blok paraffin (blocking). Blok jaringan disayat (sectioning) menggunakan mikrotom dengan ketebalan $4 \mu \mathrm{m}$ kemudian irisan diletakkan pada tissue bath, lalu diambil dengan gelas objek untuk selanjutnya diinkubasikan ke dalam slide warmer.

\section{Pewarnaan Hematoksilin-Eosin}

Pewarnaan dimulai dengan proses deparafinisasi menggunakan silol I selama 5 menit, dan silol II selama 2 menit. Kemudian dilanjutkan dengan proses rehidrasi dengan alkohol menurun dari alkohol absolut I dan II, alkohol 96\% I dan II, alkohol 90\% masing-masing selama 2 menit, selanjutnya slide jaringan dibilas dengan air mengalir. Proses selanjutnya adalah merendamkan slide jaringan di dalam larutan hematoksilin selama 5 menit, kemudian slide jaringan dibilas dengan air mengalir. Setelah itu, slide jaringan dimasukkan ke dalam larutan eosin selama 5 menit. Kemudian dilakukan proses dehidrasi kembali dengan alkohol 96\% I dan II, absolut I dan II masing-masing dua kali celup. Setelah itu, dilakukan proses clearing dengan silol I, II, dan III masingmasing 3 menit, lalu dilakukan mounting dengan Entel$\operatorname{lan}^{\circledast}$ (Kiernan 1990). Pengamatan dilakukan dengan menggunakan mikroskop cahaya (Olympus $\left.\mathrm{CX}_{31}\right)^{\circledR}$ 
dan dilanjutkan dengan pengambilan foto menggunakan kamera mikroskop Sigma ${ }^{\oplus}$, dan pengukuran secara mikroskopis menggunakan toupview application program.

\section{Histomorfometri Penis}

Pengamatan dan pengukuran histomorfometri penis dilakukan terhadap tiga penis per masingmasing bagian, yaitu radix, corpus dan glans penis. Adapun bagian yang diukur meliputi ketebalan epitel uretra, ketebalan tunika albugenia pada corpora cavernosa, dan corpus spongiosum. Untuk mengukur semua parameter tersebut, digunakan toupview application program dengan menghubungkan mikroskop cahaya (Olympus $\left.\mathrm{CX}_{31}\right)^{\circledR}$ dengan kamera Sigma ${ }^{\circledast}$ dan komputer. Setelah terhubung, dilakukan penarikan garis lurus berwarna merah dengan ketentuan sudut penarikan garis yaitu $90^{\circ}$. Pengukuran ketebalan epitel uretra dilakukan dengan cara mengambil rata-rata dari empat sisi uretra, yaitu sisi atas, sisi bawah, sisi kanan, dan sisi kiri, sedangkan untuk ketebalan tunika albugenia pada corpora cavernosa diambil dengan cara mengukur rata-rata dari setiap sisi corpus cavernosus kanan dan corpus cavernosus kiri.

\section{Analisis Data}

Data hasil pengujian di laboratorium dianalisis secara deskriptif dan disajikan dalam bentuk tabel dan gambar.

\section{HASIL}

\section{Histologi Penis Kuda Gayo}

Hasil pengamatan terhadap penis kuda gayo, diketahui bahwa penis kuda gayo terdiri dari tiga bagian yaitu radix, corpus, dan gland penis, masingmasing dari bagian tersebut terdiri dari dua jaringan erektil dan satu uretra. Dua jaringan erektil ini disebut corpus cavernosum dan corpus spongiosum. Corpus spongiosum terletak dibagian ventral dan membungkus uretra. Setiap cavernosa dibungkus oleh tunika albuginea yang mengandung banyak jaringan ikat serabut kolagen dan elastis. Pada kuda gayo, radix dan corpus penis terdiri dari jaringan ikat, otot polos dan sinosoid cavernosal. Gambaran histologi radix dan corpus penis kuda gayo masing-masing disajikan pada Gambar 1 dan 2.

Corpus cavernosum terbagi menjadi tiga bagian, yaitu satu pada bagian central dan dua pada bagian lateral. Bagian central merupakan bagian yang terpanjang dan berjalan sampai ke glans penis. Corpus cavernosum terdiri dari sinusoid dan endotel selapis yang dimulai dari bagian tengah penis dan berakhir pada ischia tuberosity. Corpus spongiosum merupakan area kecil yang mengelilingi uretra dan berfungsi saat ereksi serta memiliki tunika albuginea yang tipis. Corpus spongiosum memiliki trabekula yang lebih tipis dengan ruang cavernosa yang lebih besar dan mirip seperti vena yang terlihat di corpus cavernosum. Corpus cavernosum dan corpus spongiosum ditutup oleh jaringan ikat yang sangat tebal

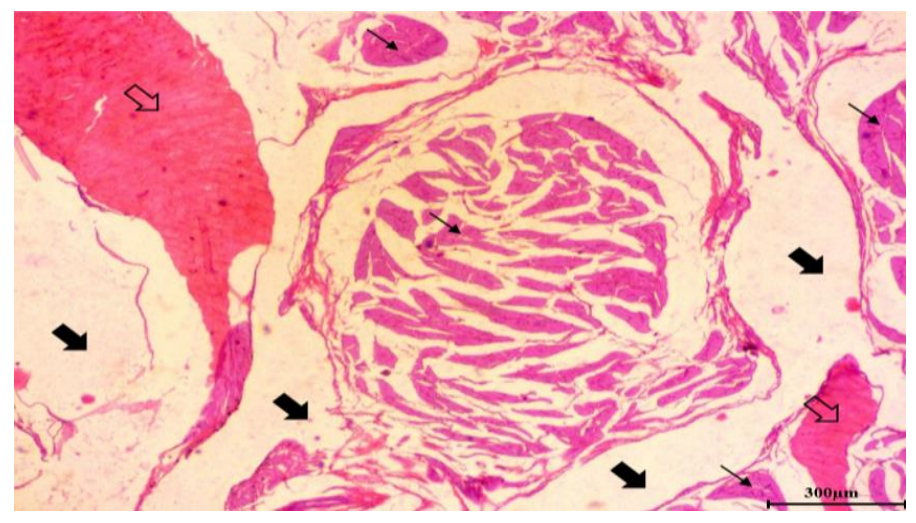

Gambar 1 Gambaran histologi radix penis kuda gayo. Tanda panah hitam tipis = Otot Polos, Tanda panah putih = Jaringan Ikat, Tanda panah hitam = Sinosiod Cavernosal (Pewarnaan HE, Perbesaran 40x) 


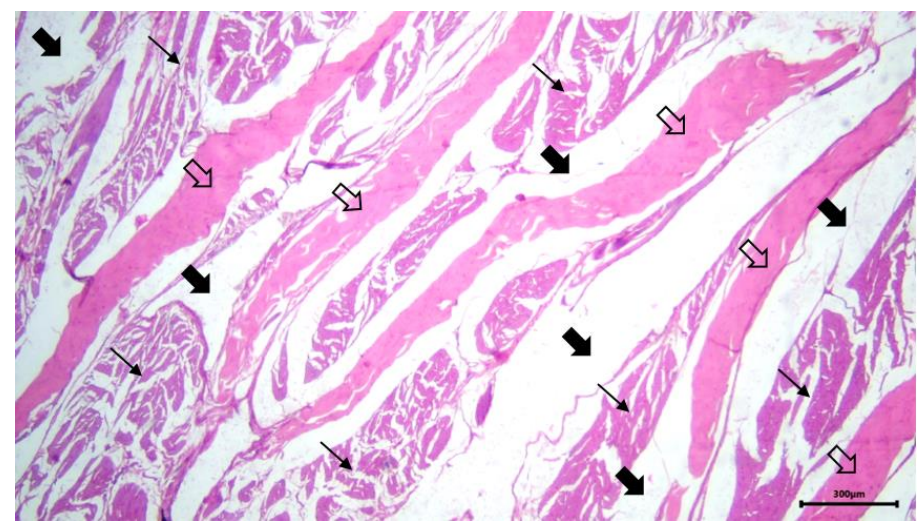

Gambar 2 Gambaran histologi corpus penis kuda gayo. Tanda panah hitam tipis = Otot Polos, Tanda panah putih = Jaringan Ikat, Tanda panah hitam = Sinosiod Cavernosal (Pewarnaan HE, Perbesaran 40x)

disebut tunika albuginea. Tunika albuginea penis kuda gayo mengandung banyak jaringan ikat serabut kolagen dan elastis yang berperan penting dalam mekanisme ereksi penis. Gambaran histologi tunika albugenia penis kuda gayo disajikan pada Gambar 3.

Glans penis adalah bagian paling distal dari penis dan memiliki dua bagian yang berbeda, yaitu leher dan korona glandis. Histologis glans penis kuda gayo terdiri dari corpus cavernosum, corpus spongiosum, uretra, dan sinus uretra. Sinus uretra tersusun atas epitel silindris berlapis, kelenjar erektil dan smegma. Gambaran histologi sinus uretra pada glans penis kuda gayo disajikan pada Gambar 4.

Uretra kuda gayo memiliki dua lamina yaitu lamina epithelia yang terdiri dari epitel silindris berlapis dan lamina propia yang tersusun oleh jaringan ikat dan pembuluh darah. Gambaran histologi uretra kuda gayo disajikan pada Gambar 5 .

\section{Histomorfometri Penis Kuda Gayo}

Hasil pengukuran histomorfometri pada penis kuda gayo yaitu, ketebalan epitel uretra pada bagian glans dan ketebalan tunika albugenia pada bagian radix dan corpus penis disajikan pada Tabel 1.

Berdasarkan Tabel 1 terlihat bahwa ketebalan lapisan tunika albugenia pada bagian radix adalah $2.181,10 \pm 48,50 \mu \mathrm{m}$, dan pada bagian corpus penis adalah 2.366,51 $\pm 131,48 \mu \mathrm{m}$. Tunika albugenia merupakan selubung fibrosa yang berbentuk kapsul dan berperan penting ketika ereksi, berada pada lapisan terluar dari corpus spongiosum serta corpus cavernosum.
Tunika albugenia juga membungkus testis, banyak mengandung serabut saraf dan pembuluh darah yang terlihat berkelok-kelok. Ketebalan epitel pada bagian uretra adalah 50,02 $\pm 6,95 \mu \mathrm{m}$.

\section{PEMBAHASAN}

Radix merupakan bagian pakal dari penis. Menurut Amann (1981), Little dan Holyoak (1992) dan Wardana (2016), radix dibentuk oleh dua crura yang merupakan perpanjangan dari corpus cavernosum yang berakhir di kedua sisi lengkung ischia dan terdiri dari bulbus, musculus ischiocavernosus, dan bulbospongiosus.

Corpus penis kuda gayo banyak terdapat otot polos, jaringan ikat dan sinusoid cavernosal, sama seperti yang pernah dilaporkan oleh Hsu dan Shih (2018), bahwa di dalam corpus cavernosum, terdapat sinusoid cavernosal yang terdiri dari jaringan ikat fibroelastis, serat otot polos dan fibroblast. Hsu dan Shih (2018) juga menuliskan jaringan ikat tersebut lebih tebal dan lebih kuat di bagian lateral cavernosum daripada bagian central, yang memiliki ruang cavernosa yang lebih besar secara diametric.

Corpus spongiosum merupakan area kecil yang mengelilingi uretra. Comelis et al. (2017) menyebutkan bahwa corpus spongiosum sebagian besar berada pada bagian glans penis dan menipis ketika meatus terjadi pada uretra. Corpus spongiosum juga berfungsi sebagai pelindung saat uretra terbuka ketika kopulasi (Hatzichristou et al. 2003). Corpus cavernosum dan corpus spongiosum ditutup oleh tunika albuginea yang banyak mengndung jaringan 


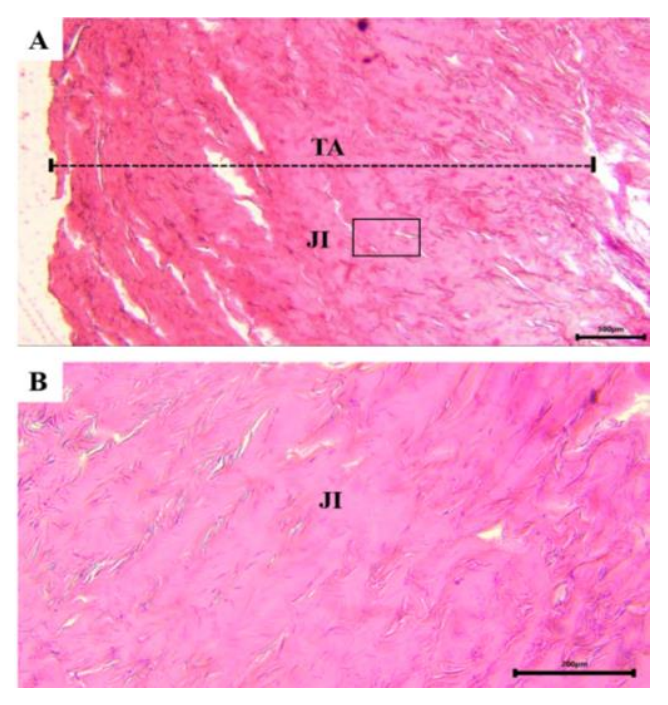

Gambar 3 Gambaran histologi tunika albugenia kuda gayo yang mengandung jaringan ikat serabut kolagen. A. Gambaran histologi tunika albugenia kuda gayo B. Insert dari gambar A. TA = Tunika Albugenia, $\mathrm{JI}=$ Jaringan Ikat Serabut Kolagen. (Pewarnaan HE, Perbesaran 40x (A) dan 100x (B))

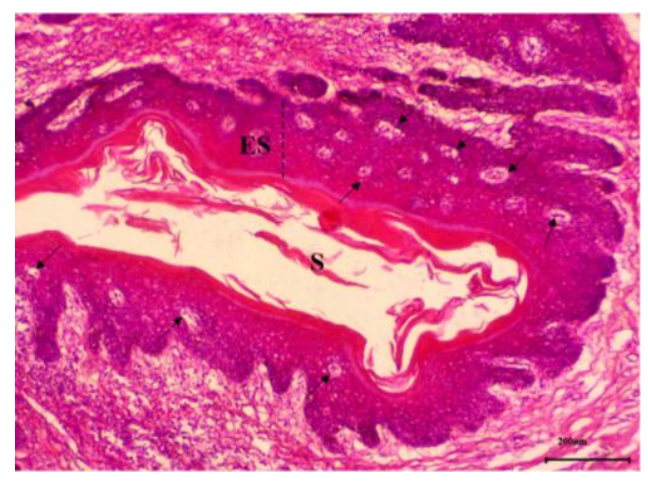

Gambar 4 Gambaran histologi glans penis kuda gayo. ES = Epitel Silindris Berlapis, $\mathrm{S}=$ Smegma, Tanda panah tipis = Kelenjar Erektil (Pewarnaan HE, Perbesaran 100x)

ikat kolagen dan elastis. Menurut Wardana (2016), tunika albuginea akan menekan vena-vena di regio subtunika sehingga menahan tekanan aliran darah balik vena selama ereksi pada penis.

Glans penis adalah bagian paling distal dari penis dan memiliki dua bagian yang berbeda, yaitu leher dan korona glandis. Little dan Holyoak (1992) dan Pozor (2014) menjelaskan bahwa pada glans penis, bagian yang berperan dalam ereksi adalah corpus spongiosum glandis. Corpus spongiosum glandis mengandung banyak jaringan erektil dan merupakan kelanjutan langsung dari corpus spongiosum. Histologis glans penis kuda gayo terdiri dari corpus cavernosum, corpus spongiosum, uretra, dan sinus uretra. Sinus uretra tersusun atas epitel silindris berlapis, kelenjar erektil dan smegma. Bacha dan Bacha
(2000) menyatakan bahwa, sinus uretra hanya terdapat pada kuda jantan dan terdapat smegma di bagian lumennya. Smegma tersusun dari deskuamasi sel epitel dan sekresi dari kelenjar preputial.

Terdapat dua lamina pada uretra kuda gayo yaitu lamina epithelia yang terdiri dari epitel silindris berlapis dan lamina propia yang tersusun oleh jaringan ikat dan pembuluh darah. Hal ini sama dengan pernyataan Bacha dan Bacha (2000), yaitu pada uretra kuda dijumpai epitel silindris berlapis dan lamina propria. Sedangkan Comelis et al. (2017), menyatakan pada uretra kelelawar ditemukan sel epitel berlapis transisional dan panjang uretra menutupi sebagian besar panjang glans. Pada penelitian ini juga dilakukan pengukuran histomorfometri penis kuda gayo. Hasil penelitian ini merupakan laporan 


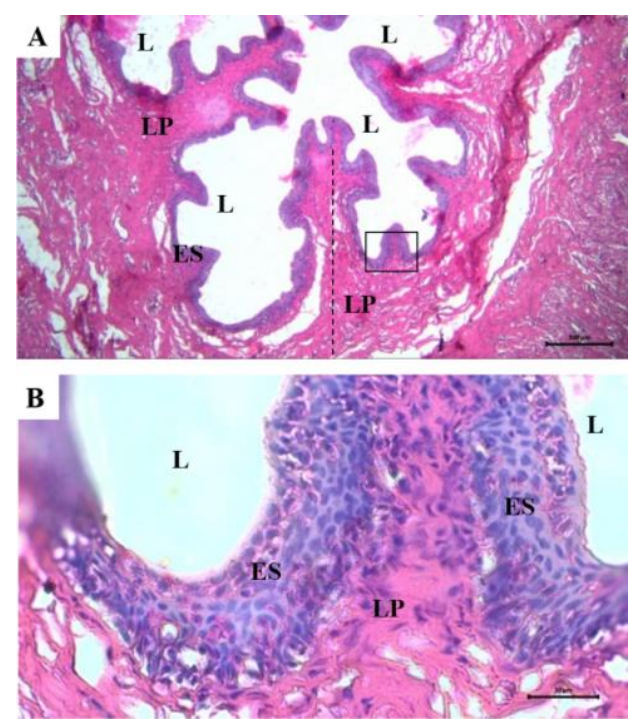

Gambar 5 Gambaran histologi uretra pada penis kuda gayo. A. Lekukan pada uretra. B. Insert dari A. L = lumen, ES = Epitel Silindris Berlapis, LP = Lamina Propria (Pewarnaan HE, Perbesaran 40x (A) dan $400 \times(B))$

Tabel 1 Ketebalan lapisan tunika albugenia dan uretra pada penis kuda gayo

\begin{tabular}{cccc}
\hline \multirow{2}{*}{ Kuda } & \multicolumn{3}{c}{ Penis $(\mu \mathrm{m})$} \\
\cline { 2 - 4 } & Retix & Corpus & Glans \\
\cline { 2 - 4 } & $2.131,44$ & $2.474,23$ & 44,47 \\
2 & $2.183,51$ & $2.219,99$ & 47,78 \\
3 & $2.228,36$ & $2.405,30$ & 57,82 \\
\hline Rata-rata & $2.181,10$ & $2.366,51$ & 50,02 \\
Standar deviasi & 48,50 & 131,48 & 6,95 \\
\hline
\end{tabular}

pertama yang mencoba mengetahui histomorfometri penis pada kuda gayo bahkan merupakan identifikasi pertama pada kuda lokal yang ada di Indonesia. Sebelumnya literatur terkait penis kuda hanya sebatas gambaran morfologi dan histologinya saja, sementara laporan terkait histomorfometri penis belum pernah dijumpai. Umumnya riset terkait histomorfometri hanya terfokus pada testis yang merupakan penghasil spermatozoa. Penelitian terkait histomorfometri pada testis beberapa diantaranya dilakukan oleh Pozor et al. (2017) pada Carthorse, Quarter Horse, dan American Miniature Horse. Begitu juga kajian histomorfometri testis pada berbagai spesies lainnya sudah banyak dilaporkan, seperti histomorfometri testis sapi fulani putih (Togun 2009), sapi shorthorn (Swierstra 1966), sapi nelore (Silva et al. 2015), kambing hitam bengal (Gofur 2015), kambing kacang dan domba lokal (Noviana et al. 2000), unta (Ibrahim et al. 2012), babi (Straaten dan Wensing 1977), dan tikus putih wistar (Miraglia dan Hisakazu 1993).

Menurut Togun (2009) ketebalan testis pada bagian tubulus seminiferous sapi fulani adalah $179,94 \pm 4,64 \mu \mathrm{m}$, Swierstra (1966) menyebutkan ketebalan testis sapi shorthorn adalah 160,5 $\pm 18,9$ $\mu \mathrm{m}$, penelitian dari Silva et al. (2015) menyebutkan testis pada sapi nelore memiliki ukuran 70,0 $\pm 0,54$ $\mu \mathrm{m}$ pada ketebalan epitel, $229,8 \pm 1,22 \mu \mathrm{m}$ pada diameter tubulus dan 3,8 $\pm 0,04 \mu \mathrm{m}$ pada tunika propria. Gofur (2015) menyebutkan pada kambing hitam bengal memiliki kelenjar vasikular yang lebih panjang di banding dengan kelenjar bulbouretralis 
$(1, .653 \pm 0,025 \mathrm{~cm}$ vs $1,045 \pm 0,038 \mathrm{~cm})$, Noviana et al. (2000) menyebutkan bahwa diameter testis kabing kacang sedikit lebih besar daripada testis domba lokal $(157,33 \pm 10,07 \mu \mathrm{m}$ vs $155,93 \pm 14,17 \mu \mathrm{m})$, penelitian dari Ibrahim et al. (2012) menyatakan bahwa sepasang testis unta memiliki ukuran 147,69 $\pm 25,39 \mathrm{~g}$, Straaten dan Wensing (1977) menyebutkan berat testis babi berumur 25 minggu adalah 158 $\pm 24 \mathrm{~g}$, Miraglia dan Hisakazu (1993) menyebutkan ukuran ketebalan diameter testis pada bagian tubulus seminiferous adalah 260,75 $\pm 3,60 \mu \mathrm{m}$.

Kesimpulan yang didapatkan dari penelitian ini adalah Penis kuda gayo terdiri dari radix, corpus dan glans penis. Radix dan corpus penis kuda gayo terdiri dari jaringan ikat, otot polos dan sinosiod cavernosal; glans penis terdapat sinus uretra yang terdiri dari epitel silindris berlapis, kelenjar erektil dan smegma.

"Penulis menyatakan tidak ada konflik kepentingan dengan pihak-pihak yang terkait dalam penelitian ini".

\section{DAFTAR PUSTAKA}

Ahmad RZ dan Anis S. 2012. Kejadian penyakit selakarang pada kuda dan cara pengendaliannya. Wartazoa. 22(2): 65-71.

Amann RP. 1981. A review of anatomy and physiology of the stallion. Equine Veterinary Science. 99: 83-105.

Arifiantini YI, Purwantara B dan Yusuf TL. 2007. Karakteristik semen segar dan kualitas semen cair kuda dalam pengencer dimitropoulos yang disuplementasi dengan fruktosa, trehalosa dan rafinosa. Media Peternakan. 30(3): 163-172.

Bacha WJ and Bacha LM. 2000. Color Atlas of Veterinary Histology. $2^{\text {nd }}$ ed. Lippincott Williams \& Wilkins, Philadelphia.

Badan Pusat Statistik. 2003. Statistik Indonesia 2003. Badan Pusat Statistik, Jakarta.

Brinsko SP. 1998. Neoplasia of the male reproductive tract. Veterinary Clinics of North America: Equine Practice. 14(3): 517-520.

Comelis MT, Larissa MB, Rejane MG, Taboga SR and Eliana MV. 2017. Morphological and histological characters of penile organization in eleven species of molossid bats. Zoology. 6(1): 1-46.

Dawood M. 2018. Histological features of penis in indigenous tom cat. Indian Journal of Natural Sciences. 8(47): 13720-13729.
Direktorat Jenderal Peternakan. Departemen Pertanian RI dan Asosiasi Obat Hewan Indonesia. 1999. Statistik Peternakan, Jakarta.

Gofur MR. 2015. Anatomy and histomorphometry of accessory reproductive glands of the black bengal buck. Europan Journal of Anatomy. 19(2): 171-178.

Harisatria D, Surtina J, Hendri dan Jaswandi. 2017. Respon estrus kuda lokal dengan induksi hormon PGF2a di kota payakumbuh. Jurnal Peternakan. 14(2): 65-69.

Hatzichristou DG, Tzortzis V, Hatzimouratidis K, Apostolidis A, Moysidis K and Panteliou S. 2003) Protective role of the glans penis during coitus. International Journal of Impotence. 15: 337-342.

Horowitz A and Rolf B. 2009. Anatomy of the Horse. $6^{\text {th }}$ ed. Hannover, Germany.

Hsu and Shih. 2018. Encyclopedia of Reproduction. $2^{\text {nd }}$ ed. Academic Press, English.

Ibrahim AA, Aliyu J, Hassan AM and Salisu N. 2012. Gonadal and extragonadal sperm reserves of camel (Camelus dromedarius) in the semi-arid region of Nigeria. ARPN Journal of Agricultural and Biological Science. 7(5): 346-350.

Kareskoski $M$ and Katila T. 2008. Components of stallion seminal plasma and the effects of seminal plasma on sperm longevity. Animal Reproduction Science. 107: 249-256.

Kiernan JA. 1990. Histological and Histochemical Method: Theory and Practice. $2^{\text {nd }}$ ed. Pertgamon Press, New York.

Little TV and Holyoak GR. 1992. Reproductive anatomy and physiology of the stallion. Veterinary Clinics of North America: Equine Practice. 8(1). 1-9.

Maswarni dan Rachman N. 2014. Kuda: Manajemen Pemeliharaan dan Pengembangan. Penebar Swadaya, Jakarta Timur.

Melia J, Agil M, Supriatna I dan Amrozi. 2016. Anatomi dan gambaran ultrasound organ reproduksi selama siklus estrus pada kuda gayo betina. Jurnal Kedokteran Hewan. 10(2): 103-108.

Melia J. 2017. Studi fisiologi reproduksi kuda gayo sebagai upaya penyelamatan plasma nutfah kuda asli Indonesia. Disertasi. Sekolah Pascasarjana Institut Pertanian Bogor, Bogor.

Memon MA, Usenik EA, Varner DD and Meyers PJ. 1988. Penile paralysis and paraphimosis associated with reserpine administration in a stallion. Theriogenology. 30(2): 411-419.

Miraglia SM and Hisakazu H. 1993. Histomorphometry of immature rat testis after heating. Journal of Morphology. 217: 65-74. 
Morel MCGD. 2008. Equine Reproductive Physiology, Breeding and Stud Management. $3^{\text {rd }}$ ed. Cambridge University Press, Cambridge.

Noviana C, Arief B dan Tutik W. 2000. Morfologi dan histomorfometri testis dan epididymis kambing kacang (Capra sp.) dan domba lokal (Ovis sp.). Media Veteriner. 7(2): 12-16.

Pozor MA. 2014. Ultrasonography of the penis. Atlas of Equine Ultrasonography. 12: 267-276.

Pozor M, Heather M, Valeria A, Natalie K, Alexis D, Margo LM and Audrey AK. 2017. Relationship between echotextural and histomorphometric characteristics of stallion testes. Theriogenology. 99(7): 134-145.

Schumacher J and Hardin DK. 1987. Surgical treatment of priapism in a stallion. Veterinary Surgery. 16(3): 193-196.

Schummer A, Nickel R and Sack. 1979. The Viscera of the Domestic Mammals. $2^{\text {nd }}$ ed. Paul Parey Verlag, Berlin.

Silva KMD, Adriane LZ, Karine BB and Carlos EDSF. 2015. Histopathological and histomorphometric testicular characteristics associated to reproductive condition in Bos indicus (Nellore) bulls. Londrina. 36(3): 1935-1944.

Straaten HWMV and Wensing CJG. 1977. Histomorphometric aspects of testicular morphogenesis in the pig. Biology of Reproduction. 17:467-472.
Swierstra EE. 1966. Structural composition of shorthorn bull testes and daily spermatozoa production as determined by quantitattve testicular histology. Canadian Journal of Animal Science. 46(14): 107-119.

Togun VA. 2009. Live weight related changes in the sperm production capacity of white fulani (Bos indicus) cattle I: testicular histomorphometry. Pakistan Journal of Biological Sciences. 12(17): 1174-1180.

Ulum MF, Paramitha D, Zultinur M, Nur FU, Nindya DU, Gunanti dan Deni N. 2013. Pencitraan ultrasonografi organ reproduksi domba jantan ekor tipis Indonesia. Acta Veterinaria Indonesiana. 1(2): 51-56.

Wardana ING. 2016. Perubahan struktur penis akibat menurunnya hormon testosteron. Tesis, Universitas Udayana, Denpasar.

Williams PL. 1995. Gray's Anatomy. $38^{\text {th }}$ ed. Churchill Livingstone, Philadelphia.

Zega I. 2015. Kualitas spermatozoa sapi limousin selama penyimpanan pada refrigerator dalam pengencer two-step extender dengan suplementasi kuning telur bebek. Tesis, Program Pascasarjana, Fakultas Matematika Dan Ilmu Pengetahuan Alam, Universitas Sumatera Utara, Med. 